\title{
CHARACTERISTICS OF DECOMPOSITION AND NUTRIENT RELEASE OF CORN STRAW UNDER DIFFERENT ORGANIC FERTILIZER REPLACEMENT RATES
}

\author{
HE, H. - ZhANG, Y. T - WEI, C. Z. - LI, J. H.* \\ Key Laboratory of Oasis Eco-Agriculture, Xinjiang Production and Construction Corps, College \\ of Agronomy, Shihezi University, Road of North 4th, Shihezi City, Xinjiang 832003, China \\ *Corresponding author \\ e-mail:ljh630703@163.com \\ (Received $2^{\text {nd }}$ Jul 2019; accepted $2^{\text {nd }}$ Sep 2019)
}

\begin{abstract}
In this study, the nylon net bag method was used to explore the characteristics of straw decomposition and nutrient release under different organic fertilizer replacement rates, which provided a scientific basis for rational straw returning in corn (Zea mays L.) planting. The results showed that the characteristics of straw decomposition and nutrient release in different treatments were fast in the early stage (0-20 d) and slow in the late stage (20-100 d). At the end of decomposition (100 d), the decomposition rate and nutrient release rate were $47.69 \%-56.07 \%, 47.55 \%-61.73 \%, 47.40 \%-62.67 \%$, 48.04\%-66.35\% and $82.20 \%-100.00 \%$, respectively, decomposition rate and nutrient release rate were $8 \% \mathrm{OF}$ (organic fertilizer replaces $8 \% \mathrm{~N}$ fertilizer) $>16 \% \mathrm{OF}$ (organic fertilizer replaces $16 \% \mathrm{~N}$ fertilizer) $>24 \% \mathrm{OF}$ (organic fertilizer replaces $24 \% \mathrm{~N}$ fertilizer) $>\mathrm{CF}$ (only chemical fertilizer) $>\mathrm{CK}$ (no fertilizer control). Through the model $\left(\mathrm{y}=\mathrm{a} \cdot \mathrm{x}^{\mathrm{b}}\right)$ analysis of nutrient release rate, the time until complete release of C, N, P, and K was predicted to be 206-275 d, 167-271 d, 153-248 d, and 85-150 d, respectively, and it was verified that the nutrient release characteristics of fertilization treatment $(\mathrm{CF}$, $8 \% \mathrm{OF}, 16 \% \mathrm{OF}, 24 \% \mathrm{OF})$ in this experiment were potassium $(\mathrm{K})>$ phosphorus $(\mathrm{P})>$ nitrogen $(\mathrm{N})>$ carbon $(\mathrm{C})$, and $\mathrm{CK}$ was $\mathrm{K}>\mathrm{P}>\mathrm{N} \approx \mathrm{C}$. Based on the model and correlation analysis, the recommended organic fertilizer replacement rate is $12 \%$, and according to the characteristics of straw decomposition and nutrient release, a strategy of rational straw returning and fertilization management was proposed.
\end{abstract}

Keywords: corn straw returning, corn planting, nutrient, fertilizer reduction, fertilization strategy, model, prediction

\section{Introduction}

Corn is China's main food and feed crop, and it plays an important strategic role in achieving food security. Excessive application of chemical fertilizers in agricultural production to ensure the increase of crop yields has caused problems such as increased planting costs, low nutrient use efficiency, reduced soil fertility, and agricultural nonpoint source pollution, and threatened the sustainable development of agro-ecology in China (Fischer, 2010; Jin and Zhou, 2018). In the past decade, corn has contributed $31.8 \%$ of the total increase in chemical fertilizer use in China. In 2015, the Ministry of Agriculture of China put forward the 2020 Fertilizer Use Zero Growth Action Plan to reduce the use of chemical fertilizers (Jin et al., 2015). Therefore, reducing the consumption of chemical fertilizer in corn production is bound to be conducive to the realization of "Fertilizer Use Zero Growth". The increase in corn yield also produces many straw resources. Crop straw is a kind of biomass resource, but it has not been used reasonably. There are high amounts of straws being burned and discarded, which not only causes waste of resources but also brings a series of environmental issues, among them, straw burning has discharged many $\mathrm{CO}_{2}, \mathrm{CO}$, particulate matter, etc., 
which wastes biomass energy and causes losses for the agricultural carbon pool, serious air pollution and soil health hazards (Feng et al., 2011; Sun et al., 2016; Li and Wang, 2013; Zhang et al., 2016). Therefore, reducing the use of chemical fertilizers and the effective use of straw resources has become a major challenge for sustainable development of green and traditional agriculture.

At present, straw returning and organic fertilizer replacing part of chemical fertilizer has become the main measures to realize the effective utilization of straw resources and reduce the use of chemical fertilizer. After organic fertilizer replaces part of chemical fertilizer, it can reduce the amount of chemical fertilizer, improve the physical and chemical properties and buffering properties of soil, improve soil fertility and microbial activity, and coordinate the balanced supply of nutrients in soil (Liu et al., 2013; Fu et al., 2017; Wen et al., 2018). Crop straw is an important renewable resource in the agricultural ecosystem. It contains abundant $\mathrm{C}, \mathrm{N}, \mathrm{P}, \mathrm{K}$ and trace elements (Wang et al., 2010). After returning to the field, soil microorganisms and enzymes act together to decompose, release $\mathrm{C}, \mathrm{N}, \mathrm{P}, \mathrm{K}$ and other nutrients to the soil, and provide crop absorption and utilization (Becker et al., 2014), which can improve soil fertility and soil physical and chemical properties, it can reduce the negative impact of burning straw on the ecological environment. Straw returning is the most economical and sustainable way to use straw resources (Yin et al., 2017).

In recent years, to solve the problems of waste of agricultural resources and alleviate the excessive application of chemical fertilizer, soil degradation and agricultural non-point source pollution, the nutrients released during the decomposition of crop straw are used to reduce the amount of chemical fertilizer application. Therefore, the research on crop straw decomposition has become a hot topic of many scholars' attention (Abdou et al., 2016; Wang et al., 2018; Gong et al., 2018). Some studies have found that with the increase of decomposition days, the decomposition rate and nutrient release rate of straw gradually increase and the decomposition speed gradually decreases. The decomposition rate of different straws is fast in the early stage and slow in the later stage (Li et al., 2009; Dai et al., 2010; Dai et al., 2017). The application of chemical fertilizer or decomposition agent in the soil can promote the decomposition of straw (Chen et al., 2016; Ngatia et al., 2014). For the different crop straw or the different forms and contents of nutrients in the straw, the release rates of nutrients are different. Some studies found that $\mathrm{K}>\mathrm{P}>\mathrm{N}>\mathrm{C}$ (Dai et al., 2010; Wu et al., 2011), and others found that K > P > C > N (Li et al., 2017). Therefore, the study of the characteristics of straw decomposition and nutrient release is the theoretical basis for guiding straw returning in agricultural production.

There are many studies on straw decomposition, but there are few studies on straw decomposition under different organic fertilizer replaces chemical fertilizer rate. Xinjiang Province is one of the major corn planting regions in China. The resources of corn straw are abundant but not effectively utilized, and it has great potential to straw returning. At the same time, the phenomenon of excessive fertilization in production is more common. Therefore, this study is based on the phenomenon that straw resources are not effectively utilized and excessive fertilization. The nylon net bag method was used to carry out decomposition experiments because this method has little impact on soil water transport and is closer to the actual situation in the field; this method is suitable for studying the decomposition of crop straw in arid and semiarid regions (Lin et al., 1992; Bocock and Gilbert, 1957). To explore the 
characteristics of decomposition and nutrient release of corn straw under different organic fertilizer replacement rate under equal nutrient conditions, establish and analyse decomposition and nutrient models, dynamically monitor and predict them, and recommend suitable organic fertilizer replacement rate, To provide a scientific basis for straw returning and rational fertilization in corn cultivation is of great significance for the effective utilization of straw resources and to reduce chemical fertilizer application and sustainable development of agriculture.

\section{Materials and methods}

\section{Site description}

The experimental site is located in the Demonstration Park of Agricultural Technology (DPAT) in Yining, Xinjiang, Northwest China (435' $30^{\prime \prime} \mathrm{N}$, $81^{\circ} 33^{\prime} 29^{\prime}$ ' $\mathrm{E}$ ), the site has an elevation of $683 \mathrm{~m}$ and is moderate temperate arid inland mountain climate, four seasons are clear and sunshine is sufficient. The annual precipitation is $250-551.7 \mathrm{~mm}$, the annual average temperature and maximum temperature are $10.6{ }^{\circ} \mathrm{C}$ and $35.8^{\circ} \mathrm{C}$, respectively, the effective accumulated temperature $\geq 10{ }^{\circ} \mathrm{C}$ is $3621.2^{\circ} \mathrm{C}$, the annual duration of sunshine is $2792.7 \mathrm{~h}$, and the frostless season is 154-184 d. The soil type is irrigated lime-calcareous soil, and the physicochemical properties of the soil tillage layer $(0-20 \mathrm{~cm})$ are as follows: $\mathrm{pH}, 7.71$; alkali $\mathrm{N}, 85.95 \mathrm{mg} \mathrm{kg}^{-1}$; available $\mathrm{K}$, available $\mathrm{P}, 23.94 \mathrm{mg} \mathrm{kg}^{-1} ; 229.24 \mathrm{mg} \mathrm{kg}^{-1}$; soil organic C, $7.38 \mathrm{~g} \mathrm{~kg}^{-1}$; total $\mathrm{N}, 0.96 \mathrm{~g} \mathrm{~kg}^{-1}$.

\section{Materials}

The experimental straw is corn straw (comprised the stems, leaves, and sheaths) preserved after harvesting and drying in the experimental site in 2017, and its initial nutrient contents were as follows: $\mathrm{C}, 413.50 \mathrm{~g} \mathrm{~kg}^{-1} ; \mathrm{N}, 19.47 \mathrm{~g} \mathrm{~kg}^{-1} ; \mathrm{P}, 3.09 \mathrm{~g} \mathrm{~kg}^{-1}$; and $\mathrm{K}, 17.53 \mathrm{~g} \mathrm{~kg}^{-1}, \mathrm{C} / \mathrm{N}$ ratio, $21.24, \mathrm{C} / \mathrm{P}$ ratio, $133.82, \mathrm{C} / \mathrm{K}$ ratio, 23.59. The local conventional fertilizers (NPK fertilizer) mainly uses urea (contains $46.0 \% \mathrm{~N}$ ), diammonium phosphate (contains $18.0 \% \mathrm{~N}, 48.0 \% \mathrm{P}_{2} \mathrm{O}_{5}$ ), potassium sulfate (contains $51.0 \% \mathrm{~K}_{2} \mathrm{O}$ ); the commercial organic fertilizer (contains $1.77 \% \mathrm{~N}, 1.95 \% \mathrm{P}_{2} \mathrm{O}_{5}, 0.53 \%$ $\left.\mathrm{K}_{2} \mathrm{O}\right)$.

\section{Experimental design}

The experiment was conducted from 8 May to 16 August 2018. On the basis of equal nutrient conditions, straw decomposition experiments under different organic fertilizer replacement rates were carried out, and five treatments were set up: (1) CK: no fertilizer control; (2) CF: only chemical fertilizer; (3) $8 \% \mathrm{OF}$ : organic fertilizer replaces $8 \% \mathrm{~N}$ fertilizer; (4) 16\%OF: organic fertilizer replaces $16 \% \mathrm{~N}$ fertilizer; (5) 24\%OF: organic fertilizer replaces $24 \% \mathrm{~N}$ fertilizer. Before spring tillage, commercial organic fertilizer, $40 \% \mathrm{~N}$ fertilizer and $\mathrm{P}$ and $\mathrm{K}$ fertilizer were applied as base fertilizer, and the remaining $60 \% \mathrm{~N}$ fertilizer was artificially applied urea (ditch application) at jointing stage. The fertilization scheme is shown in Table 1. Random block arrangement was adopted, with three replicates per treatment, and the area of the plot was $32.4 \mathrm{~m}^{2}(4 \mathrm{~m} \times 8.1 \mathrm{~m})$, and the corn (Zea mays L., $c v$. Xinyu 50) is planted in the plot, the row spacing is $50.0 \mathrm{~cm}$ ( 8 rows in total), plant spacing is 21.5 $\mathrm{cm}$, the planting density is $9.3 \times 10^{4}$ plants $\mathrm{hm}^{-2}$. 
Table 1. Fertilization schemes for different treatments

\begin{tabular}{c|c|c|c|c|c|c|c|c|c|c|c}
\hline \multirow{2}{*}{ Treatment } & \multirow{2}{*}{$\boldsymbol{k}(\%)$} & \multicolumn{9}{|c|}{ Base fertilizer } & \multicolumn{2}{c|}{$\begin{array}{c}\text { Topdressing } \\
\text { chemical-N }\end{array}$} & \multicolumn{3}{c}{ Total nutrient contents } \\
\cline { 3 - 12 } & & $\mathbf{N}$ & $\mathbf{P}_{\mathbf{2}} \mathbf{O}_{\mathbf{5}}$ & $\mathbf{K}_{\mathbf{2}} \mathbf{O}$ & $\mathbf{N}$ & $\mathbf{P}_{\mathbf{2}} \mathbf{O}_{\mathbf{5}}$ & $\mathbf{K}_{\mathbf{2}} \mathbf{O}$ & $\mathbf{N}$ & $\mathbf{N}$ & $\mathbf{P}_{\mathbf{2}} \mathbf{O}_{\mathbf{5}}$ & $\mathbf{K}_{\mathbf{2}} \mathbf{O}$ \\
\hline & - & 0 & 0 & 0 & 0 & 0 & 0 & 0 & 0 & 0 & 0 \\
$\mathrm{CK}$ & 0 & 120.0 & 180.0 & 60.0 & 0 & 0 & 0 & 180.0 & 300.0 & 180.0 & 60.0 \\
$\mathrm{CF}$ & 8 & 96.0 & 153.0 & 52.5 & 24.0 & 27.0 & 7.5 & 180.0 & 300.0 & 180.0 & 60.0 \\
$8 \% \mathrm{OF}$ & 16 & 72.0 & 127.5 & 45.0 & 48.0 & 52.5 & 15.0 & 180.0 & 300.0 & 180.0 & 60.0 \\
$16 \% \mathrm{OF}$ & 24 & 48.0 & 100.5 & 37.5 & 72.0 & 79.5 & 22.5 & 180.0 & 300.0 & 180.0 & 60.0 \\
$24 \% \mathrm{OF}$ & 24
\end{tabular}

According to the organic fertilizer replacement rate $(k)$, the replacement $\mathrm{N}$ content is calculated, and the organic fertilizer dosage and PK replacement amount are calculated according to the nutrient content of organic fertilizer

The decomposition experiment adopts the nylon net bag method, and the corn straw is dried and pulverized into 3 to $5 \mathrm{~cm}$, mixed, weighed $30.0 \mathrm{~g}$ (equivalent to $5000 \mathrm{~kg} \mathrm{ha}^{-1}$, half amount of returning to the field) and then placed in a nylon net bag (whose length $\times$ width was $30 \mathrm{~cm} \times 20 \mathrm{~cm}$, with a pore diameter of $0.125 \mathrm{~mm}$ ), after which the opening of each bag was tightly closed, and the bags were laid flat about $2 \mathrm{~cm}$ high, and each treatment was 15 bags, and the experiment was a total of 75 bags ( 5 treatments $\times 3$ replicates $\times 5$ samples). After corn emerged $2-3 \mathrm{~cm}$, the bag was buried. The specific operational steps of the buried bag: at the centre of each plot, nylon net bags were buried $10 \mathrm{~cm}$ below the 2-6 inter-row tillage layers. When landfilling, the soil $10 \mathrm{~cm}$ depth between rows of corn is taken out, the soil deep in the $2 \mathrm{~cm}$ is dug out (no landfill), then the nylon net bag is laid horizontally, and then the soil is filled back and compacted to the level with the ground (Fig. 1). The experimental period was 100 days, and 15 nylon net bags were taken every 20 days for 5 times, and recorded the precipitation and temperature conditions during the decomposition period (Fig. 2). To avoid the interference of topdressing on the determination of nutrient content of corn straw residues, no topdressing was carried out in the area where straw was buried.

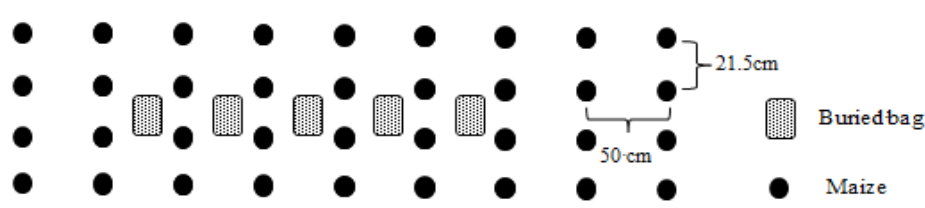

Figure 1. Schematic diagram of buried bag of corn straw

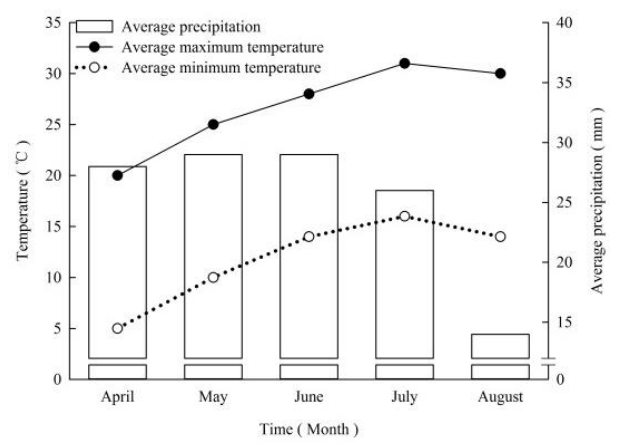

Figure 2. Temperature during decomposition experimental period 


\section{Sampling and chemical analysis}

Sampling began on May 28, 2018, sampling was performed at 20, 40, 60, 80, and 100 days (decomposition day is 20,40, 60, 80 and 100 days) after the bag was buried (sampling a total of 5 times), and August 16th, 2018 was the last sample. After sampling, the surface of the nylon net bag and the root debris were removed, and the nylon net bag was rinsed clean, then the straw in the net bag was taken out and placed in an oven (KJ-DY02, Kejie Company, China) at $65{ }^{\circ} \mathrm{C}$ to dry to constant weight. The dry weight of the straw was measured, and the sieve was passed through a $1 \mathrm{~mm}$ sieve to determine the $\mathrm{C}, \mathrm{N}, \mathrm{P}$, and $\mathrm{K}$ of the straw.

The dry matter weight of the straw was determined by a drying-weighing method. The carbon $(\mathrm{C})$ of straw was determined by potassium dichromate $\left(133 \mathrm{mmol} \mathrm{L}^{-1}\right.$ $\mathrm{K}_{2} \mathrm{Cr}_{2} \mathrm{O}_{7}$ ) external heating (at $\left.170-180^{\circ} \mathrm{C}\right)$ method. After the corn straw sample $(0.25 \mathrm{~g})$ was digested by the sulfuric acid-hydrogen peroxide $\left(\mathrm{H}_{2} \mathrm{SO}_{4}-\mathrm{H}_{2} \mathrm{O}_{2}\right)$ at $380{ }^{\circ} \mathrm{C}$, the nitrogen $(\mathrm{N})$ of straw was determined by Nessler's colorimetry method (722N, JKI Company, China), the phosphorus $(\mathrm{P})$ of straw was determined by vanadium molybdate yellow colorimetric method (722N, JKI Company, China), the potassium (K) of straw was determined by flame photometer method (FP640N, OEM Company, China). The above indicators are determined by reference to Bao (2000).

\section{Statistical analysis and calculation}

Data processing, analysis and plotting were performed using Microsoft Excel 2010 and SPSS 17.0 software. Correlation analyses were performed using the Pearson method.

Organic fertilizer replacement rates in different treatments were calculated as follows:

$$
k=\frac{\text { Organic fertilizer } \mathrm{N} \text { contact }}{\text { Total } \mathrm{N} \text { contact }}
$$

Calculate the decomposition rate, decomposition speed, nutrient release rate, and C/N ratio methods (Liu et al., 2016; Huang et al., 2017) (Eqs. 2-5):

$$
\begin{gathered}
\text { Decomposition rate }(\%)=\frac{\mathrm{M}_{0}-\mathrm{M}_{\mathrm{t}}}{\mathrm{M}_{\mathrm{o}}} \times 100 \% \\
\text { Decomposition speed }\left(\mathrm{g} \mathrm{day}^{-1}\right)=\frac{\mathrm{M}_{0}-\mathrm{M}_{\mathrm{t}}}{\mathrm{t}} \\
\text { Nutrient release rate }(\%)=\frac{\mathrm{M}_{0}-\mathrm{C}_{0}-\mathrm{M}_{\mathrm{t}} \cdot \mathrm{C}_{\mathrm{t}}}{\mathrm{M}_{\mathrm{0}} \cdot \mathrm{C}_{\mathrm{o}}} \times 100 \% \\
\text { Ratio of } \mathrm{C} \text { to nutrients in straw residue }=\frac{\mathrm{C}_{\mathrm{t}} \text { (C) }}{\mathrm{C}_{\mathrm{t}}\left(\mathrm{N}_{2} \text { P or } \mathrm{K}\right)}
\end{gathered}
$$

where $t(\mathrm{~d})$ is the decomposition day; $\mathrm{M}_{0}(\mathrm{~g})$ is the initial straw dry weight; $\mathrm{M}_{\mathrm{t}}(\mathrm{g})$ is the straw dry weight at $\mathrm{t} ; \mathrm{C}_{0}\left(\mathrm{~g} \mathrm{~kg}^{-1}\right)$ is the initial straw nutrient content; $\mathrm{C}_{\mathrm{t}}\left(\mathrm{g} \mathrm{kg}^{-1}\right)$ is the straw nutrient content at $t$.

Models of straw decomposition rate and nutrient release rate under different decomposition days (Chapman, 1997; Stanford, et al., 1972; Chen et al., 2009): 


$$
\mathrm{y}=\mathrm{a} \cdot \mathrm{x}^{\mathrm{b}}
$$

where $y$ is the decomposition rate or nutrient release rate; $\mathrm{x}$ is the decomposition day; a is the release rate of some nutrients in straw which can be achieved quickly; $b$ is the release rate growth parameter, indicating that the release rate increases faster.

\section{Results}

\section{Straw decomposition characteristics}

As the decomposition progresses, the decomposition rate increased, and the decomposition speed decreased. The whole decomposition process showed the characteristic of fast in the early stage and slows in the later stage (Fig. 3). In the first 20 days, the decomposition speed was faster, reaching $254.83-308.83 \mathrm{mg} \mathrm{d}^{-1}$ and the decomposition rate increased rapidly, reaching $16.99 \%-20.59 \%$, accounting for $33.43 \%$ $36.72 \%$ of the total decomposition rate, both decomposition rate and decomposition speed were $8 \% \mathrm{OF}>16 \% \mathrm{OF}>24 \% \mathrm{OF}>\mathrm{CF}>\mathrm{CK}$. After 20 days, the decomposition speed began to decrease, and then it was relatively stable, and the decomposition rate was slowed down. At the end of decomposition (100 d), decomposition speed was 143.33-170.00 $\mathrm{mg} \mathrm{d}^{-1}$, and the decomposition rate reached 47.69\%-56.07\%. The order of decomposition rate and decomposition speed was $8 \% \mathrm{OF}>16 \% \mathrm{OF}>24 \% \mathrm{OF}>\mathrm{CF}>\mathrm{CK}$.
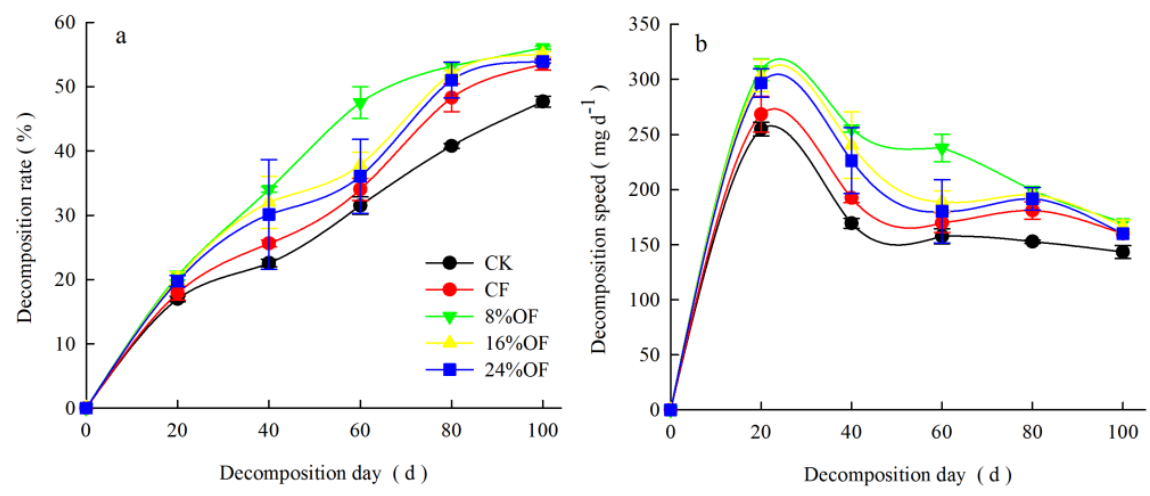

Figure 3. Decomposition characteristics of corn straw under different amounts of returned straw. In the figure, $a$ and $b$ represent the decomposition rate and decomposition speed, respectively

\section{Nutrient release characteristics}

The nutrient release characteristics are similar to the decomposition characteristics, showing that nutrient release was faster in the early stage (0-20 d) and slower in the late stage (20-100 d) (Fig. 4). The release rates of C, N, P and $\mathrm{K}$ in each treatment were $14.72 \%-25.91 \%, 14.99 \%-20.46 \%, 16.90 \%-23.68 \%$, and $42.10 \%-61.36 \%$, respectively, accounting for $30.96 \%-46.83 \%, 29.91 \%-34.79 \%, 34.15 \%-35.88 \%$ and $47.62 \%-61.36 \%$ of the total release rate, respectively, and the order of each nutrient release rate is $\mathrm{K}>\mathrm{P}>\mathrm{C}>\mathrm{N}$. After 20 days, the release rate of each nutrient increased slowly, and at 80 days, the $\mathrm{K}$ treated with $8 \% \mathrm{OF}$ had been completely released. At the end of decomposition $(100 \mathrm{~d})$, the release rates of $\mathrm{C}, \mathrm{N}, \mathrm{P}$ and $\mathrm{K}$ in each treatment were 
47.55\%-61.73\%, 47.40\%-62.67\%, 48.04\%-66.35\% and 82.20\%-100.00\% respectively. Among them, the order of release of nutrients in fertilization treatments $(\mathrm{CF}, 8 \% \mathrm{OF}$, $16 \% \mathrm{OF}$ and $24 \% \mathrm{OF}$ ) were $\mathrm{K}>\mathrm{P}>\mathrm{N}>\mathrm{C}$, and the order of release of nutrients in $\mathrm{CK}$ treatment was $\mathrm{K}>\mathrm{P}>\mathrm{N} \approx \mathrm{C}$.
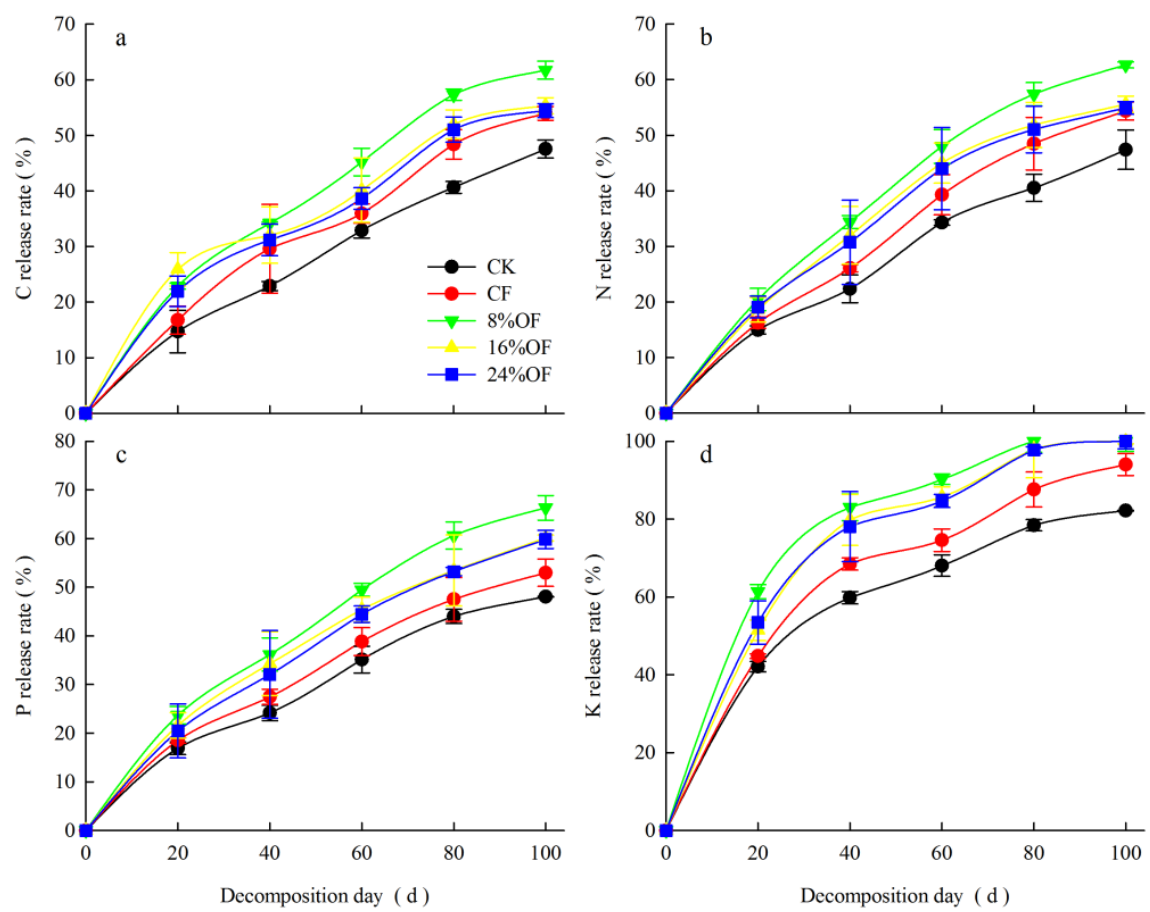

Figure 4. Dynamic changes in $C, N, P$ and $K$ release rates of corn straw. In the figure, $a, b, c$, and $d$ represent the nutrient release rates of $C, N, P$, and $K$, respectively

The rate of nutrient release from corn straw increased faster in the early stage (0$20 \mathrm{~d}$ ) and decreased in the late stage (20-100 d) (Fig. 5). In the first 20 days, the release rates of $\mathrm{C}, \mathrm{N}, \mathrm{P}$, and $\mathrm{K}$ in straw reached $91.33-160.72 \mathrm{mg} \mathrm{d}^{-1}, 4.38-5.97 \mathrm{mg} \mathrm{d}^{-1}, 0.78$ $1.10 \mathrm{mg} \mathrm{d}^{-1}$, and $11.07-16.14 \mathrm{mg} \mathrm{d}^{-1}$, respectively. After 100 days of decomposition, the release rates of $\mathrm{C}, \mathrm{N}, \mathrm{P}$, and $\mathrm{K}$ decreased to $58.98-76.58 \mathrm{mg} \mathrm{d}^{-1}, 2.60-3.55 \mathrm{mg} \mathrm{d}^{-1}, 0.45-$ $0.62 \mathrm{mg} \mathrm{d}^{-1}$, and 4.32-5.26 mg d $\mathrm{mg}^{-1}$, respectively. After 100 days of decomposition, the release rates of $\mathrm{C}, \mathrm{N}, \mathrm{P}$ and $\mathrm{K}$ decreased to $58.98-76.58 \mathrm{mg} \mathrm{d}^{-1}, 2.60-3.55 \mathrm{mg} \mathrm{d}^{-1}, 0.45$ $0.62 \mathrm{mg} \mathrm{d}^{-1}$ and $4.32-5.26 \mathrm{mg} \mathrm{d}^{-1}$, respectively, which were $35.42 \%-57.99 \%, 36.80 \%-$ $44.09 \%, 41.45 \%-43.97 \%, 58.01 \%-67.40 \%$, compared with the pre-decomposition period (0-20 d). During the whole decomposition process, the release rate of each nutrient in different treatments was $8 \% \mathrm{OF}>16 \% \mathrm{OF}>24 \% \mathrm{OF}>\mathrm{CF}>\mathrm{CK}$.

\section{Changes of $C$ and nutrients $(N, P$, and $K)$ ratio of straw residue}

As seen from Figure 6 , the $\mathrm{C} / \mathrm{N}$ ratio, the $\mathrm{C} / \mathrm{P}$ ratio and the $\mathrm{C} / \mathrm{K}$ ratio of the different treatments are substantially similar. Therefore, the different organic fertilizers replacement rate does not change the overall release characteristics of the nutrients. During the whole decomposition process, the $\mathrm{C} / \mathrm{N}$ ratio fluctuated around 21 , and there was a significant downward trend in the first 20 days. After 40 days, the $\mathrm{C} / \mathrm{N}$ ratio of each treatment ranged from 20.8 to 20.98 (Fig. 6 a). In the first 20 days, the C/P ratio increased rapidly, and $\mathrm{P}$ released the fastest. The order of the $\mathrm{C} / \mathrm{P}$ ratio was 
$8 \% \mathrm{OF}>16 \% \mathrm{OF}>24 \% \mathrm{OF}>\mathrm{CF}>\mathrm{CK}$, which was consistent with the $\mathrm{P}$ release characteristics. The $\mathrm{C} / \mathrm{P}$ ratio decreased rapidly from 20 to 40 days, and stabilized after 40 days, ranging from 115.40 to 130.94 (Fig. 6 b). The $\mathrm{C} / \mathrm{K}$ ratio continued to increase with decompression days. In the first 60 days, the order of $\mathrm{C} / \mathrm{K}$ ratio was $8 \% \mathrm{OF}>16 \% \mathrm{OF}>24 \% \mathrm{OF}>\mathrm{CF}>\mathrm{CK}$. At 80 days, $\mathrm{K}$ of $8 \% \mathrm{OF}$ was completely released. At 100 days, $\mathrm{K}$ of $16 \% \mathrm{OF}$ and $24 \% \mathrm{OF}$ was completely released, and $\mathrm{CF}$ (185.08) was higher than CK (69.54), which was consistent with the characteristics of K release (Fig. 6c).
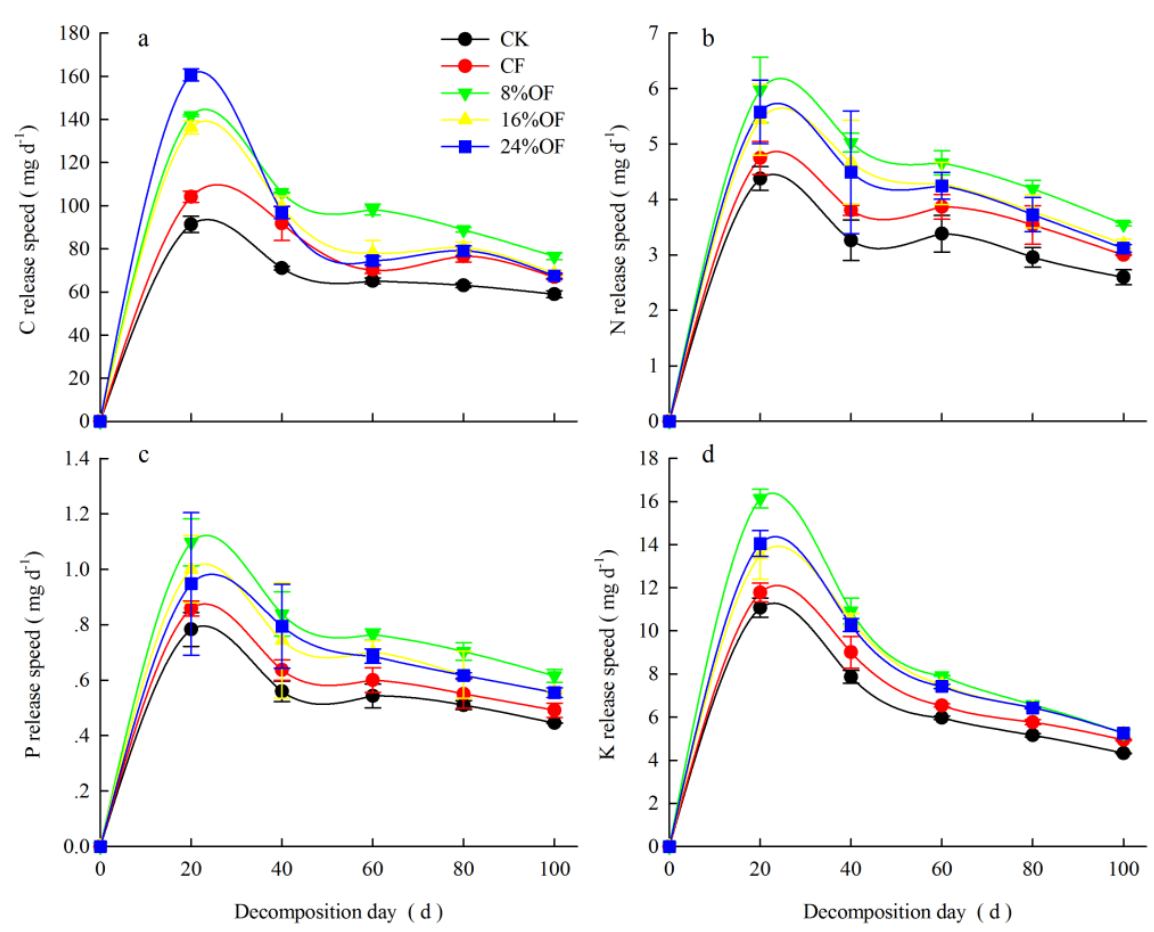

Figure 5. Dynamic changes in $C, N, P$ and $K$ release speeds of corn straw. In the figure, $a, b, c$, and $d$ represent the nutrient release speeds of $C, N, P$, and $K$, respectively
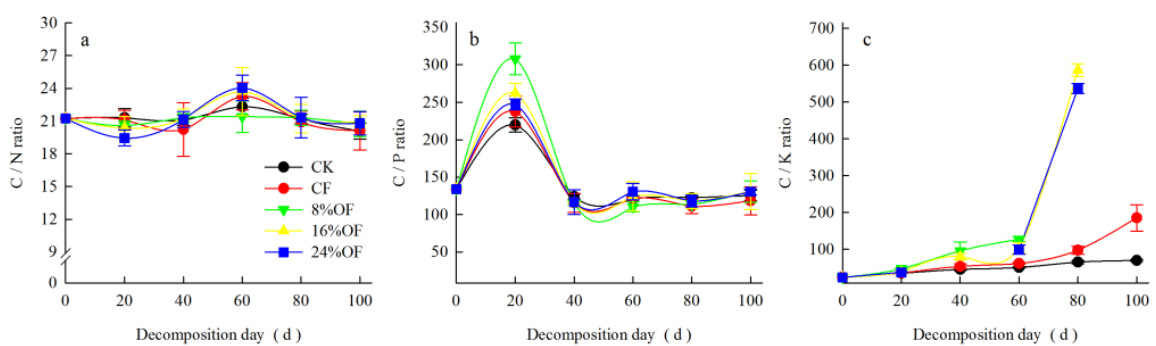

Figure 6. Changes of $C$ and nutrients $(N, P$, and $K)$ ratio of straw residue during decomposition of corn straw. In the figure, $a, b$ and $c$ represent the $C / N$ ratio, $C / P$ ratio and $C / K$ ratio, respectively

\section{Model analysis and prediction of decomposition rate and nutrient release rate}

The decomposition rate, nutrient release rate (y) and decomposition days ( $\mathrm{x}$ ) were fitted to the regression equation, in accordance with the power function model $y=a \cdot x^{b}$ 
(Table 2). It can be seen that the parameter a of the decomposition rate and the nutrient release rate of the fertilization treatments $(\mathrm{CF}, 8 \% \mathrm{OF}, 16 \% \mathrm{OF}$ and $24 \% \mathrm{OF})$ were both $8 \% \mathrm{OF}>16 \% \mathrm{OF}>24 \% \mathrm{OF}>\mathrm{CF}$, and the parameter $\mathrm{b}$ has no obvious change, therefore, fertilization can promote the decomposition and nutrient release of straw, and the treatment effect of organic fertilizer replaces chemical fertilizer is more obvious. At the same time, the model can also predict that the days of complete decomposition and $\mathrm{C} \mathrm{N}$, $\mathrm{P}$, and K complete release in different treatments are 217-330 d, 206-275 d, 167-271 d, 153-248 $\mathrm{d}$ and 85-150 d, respectively, The days required for complete decomposition is $8 \% \mathrm{OF}<16 \% \mathrm{OF}<\mathrm{CF}<24 \% \mathrm{OF}<\mathrm{CK}$ and the days required for the complete release of $\mathrm{C} \mathrm{N}, \mathrm{P}$, and $\mathrm{K}$ is $8 \% \mathrm{OF}<16 \% \mathrm{OF}<24 \% \mathrm{OF}<\mathrm{CF}<\mathrm{CK}$. The nutrient release rate of fertilization treatments $(\mathrm{CF}, 8 \% \mathrm{OF}, 16 \% \mathrm{OF}$ and $24 \% \mathrm{OF})$ were $\mathrm{K}>\mathrm{P}>\mathrm{N}>\mathrm{C}$, and the nutrient release rate of $\mathrm{CK}$ was $\mathrm{K}>\mathrm{P}>\mathrm{N} \approx \mathrm{C}$, which was consistent with the test results.

Table 2. Model analysis of decomposition time $(x)$ and decomposition rate and nutrient release rate (y) of corn straw under different treatments

\begin{tabular}{|c|c|c|c|c|c|}
\hline Item $(\%)$ & Treatments & Equation & $\mathbf{R}^{2}$ & $P$ value & Prediction days (d) \\
\hline \multirow{5}{*}{ Decomposition rate } & $\mathrm{CK}$ & $\mathrm{y}=2.2231 \mathrm{x}^{0.6566}$ & 0.9728 & 0.002 & 330 \\
\hline & $\mathrm{CF}$ & $y=2.0603 x^{0.7031}$ & 0.9759 & 0.002 & 251 \\
\hline & $8 \% \mathrm{OF}$ & $\mathrm{y}=3.0781 \mathrm{x}^{0.6472}$ & 0.9774 & $<0.001$ & 217 \\
\hline & $16 \% \mathrm{OF}$ & $\mathrm{y}=3.0109 \mathrm{x}^{0.6353}$ & 0.9846 & 0.001 & 248 \\
\hline & $24 \% \mathrm{OF}$ & $\mathrm{y}=2.8552 \mathrm{x}^{0.640}$ & 0.9796 & 0.001 & 259 \\
\hline \multirow{5}{*}{$\mathrm{C}$ release rate } & $\mathrm{CK}$ & $\mathrm{y}=1.5653 \mathrm{x}^{0.7407}$ & 0.9964 & $<0.001$ & 275 \\
\hline & $\mathrm{CF}$ & $\mathrm{y}=1.9414 \mathrm{x}^{0.7255}$ & 0.9919 & $<0.001$ & 229 \\
\hline & $8 \% \mathrm{OF}$ & $\mathrm{y}=3.3395 \mathrm{x}^{0.6383}$ & 0.9946 & $<0.001$ & 206 \\
\hline & $16 \% \mathrm{OF}$ & $y=2.6449 x^{0.6781}$ & 0.9992 & 0.003 & 213 \\
\hline & $24 \% \mathrm{OF}$ & $\mathrm{y}=2.5403 \mathrm{x}^{0.6801}$ & 0.9997 & 0.001 & 222 \\
\hline \multirow{5}{*}{$\mathrm{N}$ release rate } & $\mathrm{CK}$ & $\mathrm{y}=1.5659 \mathrm{x}^{0.7421}$ & 0.9999 & $<0.001$ & 271 \\
\hline & $\mathrm{CF}$ & $\mathrm{y}=1.7486 \mathrm{x}^{0.7491}$ & 0.9934 & $<0.001$ & 222 \\
\hline & $8 \% \mathrm{OF}$ & $\mathrm{y}=2.0592 \mathrm{x}^{0.7589}$ & 0.9931 & $<0.001$ & 167 \\
\hline & $16 \% \mathrm{OF}$ & $\mathrm{y}=1.9148 \mathrm{x}^{0.7543}$ & 0.9842 & 0.001 & 190 \\
\hline & $24 \% \mathrm{OF}$ & $\mathrm{y}=1.8954 \mathrm{x}^{0.7536}$ & 0.9883 & 0.001 & 193 \\
\hline \multirow{5}{*}{$\mathrm{P}$ release rate } & $\mathrm{CK}$ & $\mathrm{y}=1.6477 \mathrm{x}^{0.7449}$ & 0.9863 & 0.001 & 248 \\
\hline & $\mathrm{CF}$ & $\mathrm{y}=1.7839 \mathrm{x}^{0.7498}$ & 0.9938 & $<0.001$ & 215 \\
\hline & $8 \% \mathrm{OF}$ & $\mathrm{y}=2.1747 \mathrm{x}^{0.762}$ & 0.9961 & $<0.001$ & 153 \\
\hline & $16 \% \mathrm{OF}$ & $\mathrm{y}=2.0211 \mathrm{x}^{0.7574}$ & 0.9981 & $<0.001$ & 173 \\
\hline & $24 \% \mathrm{OF}$ & $\mathrm{y}=1.9719 \mathrm{x}^{0.756}$ & 0.9974 & $<0.001$ & 181 \\
\hline \multirow{5}{*}{$\mathrm{K}$ release rate } & $\mathrm{CK}$ & $\mathrm{y}=12.248 \mathrm{x}^{0.4197}$ & 0.9893 & $<0.001$ & 150 \\
\hline & $\mathrm{CF}$ & $\mathrm{y}=11.969 \mathrm{x}^{0.4526}$ & 0.9763 & 0.002 & 111 \\
\hline & $8 \% \mathrm{OF}$ & $\mathrm{y}=25.049 \mathrm{x}^{0.3109}$ & 0.9586 & 0.004 & 85 \\
\hline & $16 \% \mathrm{OF}$ & $\mathrm{y}=15.846 \mathrm{x}^{0.4121}$ & 0.9452 & 0.006 & 88 \\
\hline & $24 \% \mathrm{OF}$ & $\mathrm{y}=17.214 \mathrm{x}^{0.3913}$ & 0.9661 & 0.003 & 90 \\
\hline
\end{tabular}




\section{Correlation analysis of decomposition rate and nutrient release rate under different organic fertilizer replacement rates, and recommending organic fertilizer replacement rate}

During the whole decomposition process, there was no significant correlation $(P>0.05)$ between organic fertilizer replacement rate and decomposition rate or nutrient release rate, but there was a significant positive correlation between decomposition rate and nutrient release rate $(P<0.05)($ Table 3$)$, therefore, the nutrient release rate of the treatment with the high decomposition rate is also higher. The regression equation fitting of the relationship between organic fertilizer replacement rate ( $k$ is $0,8 \%, 16 \%$, and $24 \%$, respectively) and decomposition rate (y) conforms to the one-variable quadratic function (Schedule 1).

Table 3. Correlation analysis of decomposition rate and nutrient release rate (y) under different organic fertilizer replacement rate $(k)$

\begin{tabular}{|c|c|c|c|c|c|c|}
\hline \multirow{2}{*}{ Decomposition day } & \multirow{2}{*}{ Item } & \multirow{2}{*}{ Decomposition rate } & \multicolumn{4}{|c|}{ Nutrient release rate } \\
\hline & & & $\mathrm{C}$ & $\mathbf{N}$ & $\mathbf{P}$ & $\mathbf{K}$ \\
\hline \multirow{2}{*}{$20 \mathrm{~d}$} & $k$ & 0.570 & 0.633 & 0.495 & 0.219 & 0.303 \\
\hline & Decomposition rate & 1 & $0.947^{*}$ & $0.974^{* *}$ & $0.961^{* *}$ & $0.920^{*}$ \\
\hline \multirow{2}{*}{$40 \mathrm{~d}$} & $k$ & 0.416 & 0.176 & 0.431 & 0.410 & 0.528 \\
\hline & Decomposition rate & 1 & $0.936^{*}$ & $0.998^{* *}$ & $1.000^{* *}$ & $0.989^{* *}$ \\
\hline \multirow{2}{*}{$60 \mathrm{~d}$} & $k$ & -0.077 & 0.100 & 0.397 & 0.378 & 0.503 \\
\hline & Decomposition rate & 1 & $0.970^{* *}$ & 0.863 & $0.899^{*}$ & 0.847 \\
\hline \multirow{2}{*}{$80 \mathrm{~d}$} & $k$ & 0.439 & 0.089 & 0.071 & 0.240 & 0.658 \\
\hline & Decomposition rate & 1 & $0.963^{* *}$ & $0.961^{* *}$ & $0.885^{*}$ & $0.977^{* *}$ \\
\hline \multirow{2}{*}{$100 \mathrm{~d}$} & $k$ & 0.034 & -0.177 & -0.182 & 0.340 & 0.775 \\
\hline & Decomposition rate & 1 & $0.916^{*}$ & $0.914^{*}$ & $0.894^{*}$ & $0.965^{* *}$ \\
\hline
\end{tabular}

* and **: Correlation coefficients significant at $P<0.05$ and $P<0.01$, respectively

Schedule 1. Regression analysis of organic fertilizer replacement rate ( $k)$ and decomposition rate (y)

\begin{tabular}{c|c|c|c|c|c|c}
\hline Item $(\boldsymbol{\%})$ & $\begin{array}{c}\text { Time } \\
(\mathbf{d})\end{array}$ & Equation & $\boldsymbol{R}^{\mathbf{2}}$ & $\boldsymbol{P}$ value & $\begin{array}{c}\text { Best } \boldsymbol{k} \\
(\boldsymbol{\%})\end{array}$ & $\begin{array}{c}\text { Prediction y } \\
(\boldsymbol{k}=\mathbf{1 2 \%})(\boldsymbol{\%})\end{array}$ \\
\hline \multirow{4}{*}{$\begin{array}{c}\text { Decomposition } \\
\text { rate }\end{array}$} & 20 & $\mathrm{y}=-0.0123 \mathrm{k}^{2}+0.3606 \mathrm{k}+18.040$ & 0.8958 & 0.131 & 15 & 20.60 \\
& 40 & $\mathrm{y}=-0.0402 \mathrm{k}^{2}+1.1083 \mathrm{k}+26.147$ & 0.8565 & 0.158 & 14 & 33.66 \\
& 60 & $\mathrm{y}=-0.0598 \mathrm{k}^{2}+1.3913 \mathrm{k}+35.579$ & 0.5506 & 0.081 & 12 & 43.66 \\
& 80 & $\mathrm{y}=-0.0598 \mathrm{k}^{2}+1.3913 \mathrm{k}+35.579$ & 0.8543 & 0.410 & 14 & 53.04 \\
& 100 & $\mathrm{y}=-0.0144 \mathrm{k}^{2}+0.3501 \mathrm{k}+53.681$ & 0.8664 & 0.032 & 12 & 55.81 \\
\hline
\end{tabular}

At the end of decomposition, the best organic fertilizer replacement rate was $12 \%$, which is determined that the recommended organic fertilizer replacement rate was $12 \%$, and bring it into the (Schedule 2) equation, predicting the decomposition rates and $\mathrm{C}, \mathrm{N}$, $\mathrm{P}$ and $\mathrm{K}$ release rates for different days $(20 \mathrm{~d}, 40 \mathrm{~d}, 60 \mathrm{~d}, 80 \mathrm{~d}$ and $100 \mathrm{~d})$ ranged from $20.60 \%$ to $55.81 \%, 25.02 \%$ to $59.08 \%, 19.77 \%$ to $59.69 \%, 23.03 \%$ to $64.11 \%$ and $57.31 \%$ to $100.00 \%$, respectively. The predicted value satisfies the experiment result of 
$\mathrm{K}>\mathrm{P}>\mathrm{N}>\mathrm{C}$. Finally, the regression equation was fitted to the decomposition rate and nutrient release rate under the recommended organic fertilizer replacement rate $(k=12 \%)$, which is consistent with the power function $\mathrm{y}=\mathrm{a} \cdot \mathrm{x}^{\mathrm{b}}$ model (Table 4). Through the model, it can be predicted that the days for complete decomposition and the days for complete release of $\mathrm{C}, \mathrm{N}, \mathrm{P}$ and $\mathrm{K}$ under the organic fertilizer replacement rate of $12 \%$ are $176 \mathrm{~d}, 163 \mathrm{~d}, 159 \mathrm{~d}, 153 \mathrm{~d}$, and $65 \mathrm{~d}$, respectively (Table 4), and compared with the best treatment of $8 \% \mathrm{OF}(k=8 \%)$ in the experiment, it was advanced by $41 \mathrm{~d}, 43 \mathrm{~d}, 8 \mathrm{~d}, 0 \mathrm{~d}$, and $20 \mathrm{~d}$, respectively.

Schedule 2. Regression analysis of organic fertilizer replacement rate $(k)$ and nutrient release rate (y)

\begin{tabular}{c|c|c|c|c|c}
\hline Item (\%) & Time $(\mathbf{d})$ & Equation & $\boldsymbol{R}^{2}$ & $\boldsymbol{P}$ value & $\begin{array}{c}\text { Prediction y } \\
(\boldsymbol{k}=\mathbf{1 2 \%} \boldsymbol{( \% )}\end{array}$ \\
\hline \multirow{5}{*}{ C release rate } & 20 & $\mathrm{y}=-0.0391 \mathrm{k}^{2}+1.1716 \mathrm{k}+16.593$ & 0.9820 & 0.014 & 25.02 \\
& 40 & $\mathrm{y}=-0.0212 \mathrm{k}^{2}+0.5417 \mathrm{k}+30.023$ & 0.7031 & 0.617 & 33.47 \\
& 60 & $\mathrm{y}=-0.0422 \mathrm{k}^{2}+1.0498 \mathrm{k}+36.835$ & 0.6478 & 0.081 & 43.36 \\
& 80 & $\mathrm{y}=-0.0386 \mathrm{k}^{2}+0.9591 \mathrm{k}+49.32$ & 0.5871 & 0.024 & 55.27 \\
& 100 & $\mathrm{y}=-0.0339 \mathrm{k}^{2}+0.7523 \mathrm{k}+54.93$ & 0.5083 & 0.011 & 59.08 \\
\hline \multirow{5}{*}{ N release rate } & 20 & $\mathrm{y}=-0.0145 \mathrm{k}^{2}+0.4312 \mathrm{k}+16.681$ & 0.6193 & 0.190 & 19.77 \\
& 40 & $\mathrm{y}=-0.0373 \mathrm{k}^{2}+1.0413 \mathrm{k}+26.67$ & 0.8077 & 0.183 & 33.79 \\
& 60 & $\mathrm{y}=-0.0379 \mathrm{k}^{2}+1.0481 \mathrm{k}+39.985$ & 0.7598 & 0.102 & 47.10 \\
& 80 & $\mathrm{y}=-0.038 \mathrm{k}^{2}+0.9371 \mathrm{k}+49.445$ & 0.5630 & 0.218 & 55.22 \\
& 100 & $\mathrm{y}=-0.0349 \mathrm{k}^{2}+0.7702 \mathrm{k}+55.47$ & 0.4748 & 0.025 & 59.69 \\
\hline \multirow{5}{*}{ P release rate } & 20 & $\mathrm{y}=-0.0247 \mathrm{k}^{2}+0.638 \mathrm{k}+18.927$ & 0.7596 & 0.264 & 23.03 \\
& 40 & $\mathrm{y}=-0.0427 \mathrm{k}^{2}+1.1723 \mathrm{k}+27.978$ & 0.8744 & 0.415 & 35.9 \\
& 60 & $\mathrm{y}=-0.0453 \mathrm{k}^{2}+1.2474 \mathrm{k}+39.711$ & 0.7263 & 0.018 & 48.16 \\
& 80 & $\mathrm{y}=-0.0522 \mathrm{k}^{2}+1.3782 \mathrm{k}+48.861$ & 0.5717 & 0.143 & 57.88 \\
& 100 & $\mathrm{y}=-0.0535 \mathrm{k}^{2}+1.4628 \mathrm{k}+54.256$ & 0.6384 & 0.024 & 64.11 \\
\hline \multirow{5}{*}{ K release rate } & 20 & $\mathrm{y}=-0.0569 \mathrm{k}^{2}+1.5666 \mathrm{k}+46.706$ & 0.4714 & 0.091 & 57.31 \\
& 40 & $\mathrm{y}=-0.0634 \mathrm{k}^{2}+1.8421 \mathrm{k}+69.468$ & 0.8403 & 0.013 & 82.44 \\
& 60 & $\mathrm{y}=-0.0652 \mathrm{k}^{2}+1.886 \mathrm{k}+75.804$ & 0.7854 & 0.001 & 89.05 \\
& 80 & $\mathrm{y}=-0.0492 \mathrm{k}^{2}+1.5342 \mathrm{k}+88.435$ & 0.8581 & $<0.001$ & 99.76 \\
& 100 & $\mathrm{y}=-0.0233 \mathrm{k}^{2}+0.7823 \mathrm{k}+94.338$ & 0.9333 & $<0.001$ & 100.00 \\
\hline
\end{tabular}

Table 4. Model of corn straw decomposition and nutrient release under recommended organic fertilizer replacement rate $(k=12 \%)$

\begin{tabular}{c|c|c|c|c}
\hline Item $(\%)$ & Equation & $\boldsymbol{R}^{2}$ & $\boldsymbol{P}$ value & Time prediction $(\mathbf{d})$ \\
\hline Decomposition rate & $\mathrm{y}=0.7872 \mathrm{x}^{0.9856}$ & 0.9995 & $<0.001$ & 176 \\
C release rate & $\mathrm{y}=1.8596 \mathrm{x}^{0.7828}$ & 0.9996 & $<0.001$ & 163 \\
N release rate & $\mathrm{y}=1.8764 \mathrm{x}^{0.7844}$ & 0.9999 & $<0.001$ & 159 \\
P release rate & $\mathrm{y}=1.928 \mathrm{x}^{0.7851}$ & 0.9999 & $<0.001$ & 153 \\
K release rate & $\mathrm{y}=3.3484 \mathrm{x}^{0.8138}$ & 0.9987 & $<0.001$ & 65 \\
\hline
\end{tabular}

As shown in Figure 7, it is recommended that the straw returned per hectare under the replacement rate of organic fertilizer, after 100 days of decomposition, the release 
amounts of $\mathrm{C}, \mathrm{N}, \mathrm{P}$, and $\mathrm{K}$ are $1209.26 \mathrm{~kg}, 57.53 \mathrm{~kg}, 9.81 \mathrm{~kg}$, and $86.77 \mathrm{~kg}$, respectively. Among them, most of the nutrients released in the first 20 days were $512.12 \mathrm{~kg}, 19.05 \mathrm{~kg}, 3.52 \mathrm{~kg}$, and $49.73 \mathrm{~kg}$, accounting for $42.35 \%, 33.12 \%, 35.92 \%$, $57.31 \%$ of the total release of $\mathrm{C}, \mathrm{N}, \mathrm{P}$ and $\mathrm{K}$, which accorded with the characteristics of decomposition and nutrient release in this experiment.

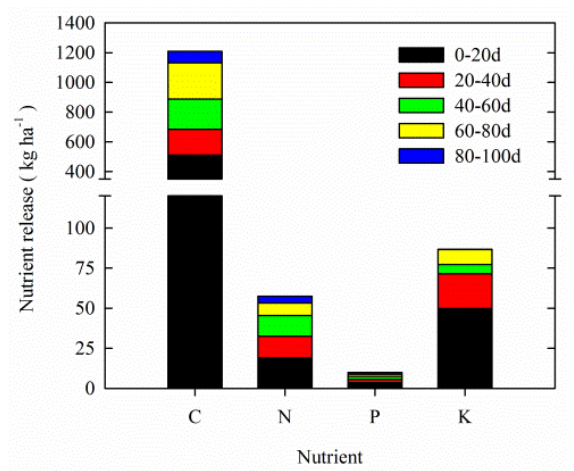

Figure 7. Nutrient release under recommended organic fertilizer replacement rate $(k=12 \%)$ during corn growth period

\section{Discussion}

\section{Decomposition and nutrient release characteristics of straw}

\section{(1) Decomposition characteristics}

This study found that the characteristics of decomposition and nutrient release during the whole decomposition process are fast in the early stage (0-20 d) and slow in the later stage (20-100 d), which is similar to previous studies (Wu et al., 2011; Zhao et al., 2011; Yang et al., 2015). It may be because: in the early stage of decomposition, corn straw contains a large amount of easily decomposable organic substances, which are easily used by microorganisms, resulting in faster decomposition; As the decomposition progresses, the easily decomposable organic matter in the straw is gradually reduced, and the remaining mainly coarse fibers and lignin which are difficult to decompose are difficult to be easily utilized by microorganisms, resulting in slow decomposition in the later stage ( $\mathrm{Li}$ et al., 2009; Summerell and Burgess, 1989). In addition, temperature and precipitation in climatic conditions can also affect straw decomposition (Gupta and Singh, 1981). This experiment began in May, when the temperature rises and precipitation increases (Fig. 1), which improves microbial activity and promotes straw decomposition. At the later stage, excessive temperature inhibited microbial activity, which inhibited straw decomposition (Zhou et al., 2015; Nakajima et al., 2016).

\section{(2) Nutrient release characteristics}

There was a significant positive correlation $(P<0.05)$ between the decomposition rate and nutrient release rate (Table 3). Therefore, the nutrient release rate of high decomposition rate treatment was also higher. At the end of the experiment $(100 \mathrm{~d})$, the order of nutrient release rate was $\mathrm{K}>\mathrm{P}>\mathrm{N}>\mathrm{C}$, which was consistent with most studies (Dai et al., 2010; Gong et al., 2018; Liu et al., 2016). The nutrient release rate depends mainly on the morphology of each nutrient $(\mathrm{C}, \mathrm{N}, \mathrm{P}$, and $\mathrm{K})$ in the straw. Among them, the $\mathrm{K}$ content in the straw is high and mainly exists in the ionic state, 
which is easy to release; The P content in the straw is low, over $60 \%$ is in the ionic state, the release is faster, and the rest is more difficult to decompose, resulting in slower release in the later stage, so the K release is faster than P (Wang et al., 2013; Dai et al., 2017). $\mathrm{C}$ and $\mathrm{N}$ are the main components of straw, mainly insoluble organic matter, which is easier to release in the early stage. The remaining part is mainly organic matter with high cementation and difficult to decompose, resulting in a slower release of C and N (Murayama, 2010; Chen et al., 2016; Tang et al., 2016).

\section{(3) Changes of $C$ and nutrients $(N, P$, and $K)$ ratio of straw residue}

Changes of $\mathrm{C}$ and nutrients $(\mathrm{N}, \mathrm{P}$, and $\mathrm{K}$ ) ratio of straw residue during the decomposition process can not only reflect the characteristics of the overall release of nutrients after the crop straw is returned to the field, but also reveal its relationship with the decomposition and nutrient release (Fig. 6). $\mathrm{C} / \mathrm{N}$ ratio of straw is a major factor affecting straw decomposition and microbial activity (Ahlam, 2004). In the first 20 days, decomposition and nutrient release was the fastest, because the reduction of $\mathrm{C} / \mathrm{N}$ ratio promoted decomposition (Dai et al., 2010), and the late $\mathrm{C} / \mathrm{N}$ ratio was close to the appropriate range of microbial growth 25-30:1 (Devêvre and Horwath, 2000), but the $\mathrm{C}$ in the straw is mainly in the form of lignin, which is difficult to be used by microorganisms, leading to the slowing down of decomposition and nutrient release (Summerell and Burgess, 1989; Li et al., 2009), and the change in $\mathrm{C} / \mathrm{N}$ ratio also reflects that the characteristics of decomposition and nutrient release is fast in the early stage (0$20 \mathrm{~d}$ ) and slow in the later stage (20-100 d) (Figs. 3-5). The change of C/P ratio and $\mathrm{C} / \mathrm{K}$ ratio of straw reflects that the release degree of nutrients of $\mathrm{C}, \mathrm{P}$ and $\mathrm{K}$ is $\mathrm{K}>\mathrm{P}>\mathrm{C}$ (Fig. 4), and reflected the characteristics of nutrient release from different treatments are $8 \% \mathrm{OF}>16 \% \mathrm{OF}>24 \% \mathrm{OF}>\mathrm{CF}>\mathrm{CK}$.

\section{(4) Models of decomposition and nutrient release}

Through the establishment of decomposition and nutrient release models (Table 2), dynamic monitoring of straw decomposition and nutrient release from different treatments can be performed, and the days for complete decomposition and complete release of nutrients can be predicted, and verified the characteristics of decomposition and nutrient release in this experiment (Figs. 3-5). Therefore, the establishment of the model helps to establish a reasonable return time, which is of great significance for guiding reasonable straw returning.

\section{Effects of different organic fertilizer replacement rates on straw decomposition and nutrient release and prediction of organic fertilizer replacement rate}

The decomposition rate and nutrient release rate were $8 \% \mathrm{OF}>16 \% \mathrm{OF}>24 \% \mathrm{OF}>\mathrm{CF}>\mathrm{CK}$ (Figs. 3-4). It can be seen that with the increase of the replacement rate of organic fertilizer, the decomposition rate, and nutrient release rate first increased and then decreased, and the fertilization treatments $(\mathrm{CF}, 8 \% \mathrm{OF}$, $16 \% \mathrm{OF}$ and $24 \% \mathrm{OF}$ ) were higher than that without fertilizer application $(\mathrm{CK})$, and the effect of organic fertilizer replacement treatment was obvious. It is because, on the one hand, chemical fertilizers are fast, but the utilization rate is low. Organic fertilizers improve soil physical and chemical properties and promote microbial activities and reproduction, but organic fertilizers release nutrients at a slower rate. The replacement of some chemical fertilizers by organic fertilizers can coordinate inorganic and organic 
nutrients, meet the nutrient requirements of crops, and improve soil fertility, thereby promoting microbial activities and straw decomposition (Hao et al., 2012). Some studies have also found that the application of chemical fertilizers in the soil can also promote the decomposition of straw, and the corn straw is decomposed faster under high fertility conditions (Zheng et al., 2004; Wang et al., 2009). According to the characteristics of fertilizer efficiency of chemical fertilizer and organic fertilizer, with the increase of organic fertilizer replacement rate, the available nutrients in the soil are reduced. The crop growth in the plot absorbs available nutrients from the soil, and there exists nutrient competition between crop growth and decomposition, thus inhibiting straw decomposition (Azam et al., 1991).

The correlation analysis (Table 3) shows the whole decomposition process. The organic replacement rate will not change the characteristics of the whole decomposition and nutrient release of corn straw, but the appropriate organic replacement rate can effectively coordinate the nutrient balance, promote the decomposition and nutrient release. Therefore, it is very important to determine the organic replacement rate for straw decomposition. In this study, model analysis of decomposition rates and nutrient release rates under different organic fertilizer replacement rates (Schedule 1) was performed to determine a recommended organic fertilizer replacement rate of $12 \%$ and a decomposition and nutrient release model was established (Table 4). Predicting the complete time required for decomposition and releasing is better than the optimal treatment $(8 \% \mathrm{OF})$. Therefore, the recommendation of the replacement rate of organic fertilizer has important guiding significance for the comprehensive management of straw returning and rational fertilization.

\section{The strategy of straw returning and rational fertilization in corn planting}

Corn is one of the three major food crops in the world. It needs a lot of nutrients; excessive application of chemical fertilizer not only increases the cost of agricultural production but also causes soil acidification and agricultural pollution. This study found that suitable organic fertilizer replacement efficiency is conducive to the efficient use of straw resources and reduce the use of chemical fertilizer. Taking this experimental area as an example, the recommended fertilization amount is $300.0 \mathrm{~kg} \mathrm{~N} \mathrm{ha}^{-1}, 180.0 \mathrm{~kg} \mathrm{P}_{2} \mathrm{O}_{5}$ $\mathrm{ha}^{-1}, 60.0 \mathrm{~kg} \mathrm{~K}_{2} \mathrm{O} \mathrm{ha}{ }^{-1}$, On the basis of recommending the replacement rate of organic fertilizer $12 \%$, the return of straw is carried out, and the fertilization scheme: the application of $\mathrm{N}, \mathrm{P}_{2} \mathrm{O}_{5}, \mathrm{~K}_{2} \mathrm{O}$ in the form of chemical fertilizer is $264.0 \mathrm{~kg} \mathrm{ha}^{-1}, 140.3 \mathrm{~kg}$ $\mathrm{ha}^{-1}$ and $49.2 \mathrm{~kg} \mathrm{ha}^{-1}$, respectively; the organic fertilizer is $2033.9 \mathrm{~kg} \mathrm{ha}^{-1} \mathrm{~kg} \mathrm{ha}^{-1}$, of which the $\mathrm{N}, \mathrm{P}_{2} \mathrm{O}_{5}, \mathrm{~K}_{2} \mathrm{O}$ contents are $36.0 \mathrm{~kg} \mathrm{ha}^{-1}, 39.7 \mathrm{~kg} \mathrm{ha}^{-1}, 10.8 \mathrm{~kg} \mathrm{ha}^{-1}$, respectively. During the growth period of corn $(100 \mathrm{~d})$, the release of $\mathrm{N}, \mathrm{P}$ and $\mathrm{K}$ was equivalent to $19.18 \%, 5.45 \%$ and $144.61 \%$ of the fertilization amount of NPK fertilizer, and the $\mathrm{K}$ release amount exceeded the fertilization amount of $\mathrm{K}$ fertilizer, at the same time, a many $\mathrm{C}$ is released (Fig. 7), which effectively increases soil organic matter content (Wang et al., 2017). According to the characteristics of nutrient release from straw, it is fast in the early stage (0-20 d), slow in the late stage (20-100 d) and $\mathrm{K}>\mathrm{P}>\mathrm{N}>\mathrm{C}$. This study proposes that organic fertilizer and straw are applied as base fertilizers, while reducing the application amount of chemical fertilizers in base fertilizers. According to the general nutrient absorption characteristics of corn, the absorption of $\mathrm{N}, \mathrm{P}$ and $\mathrm{K}$ was less in the seedling stage, the jointing stage was significantly increased, and the peak was reached from the booting stage to the heading stage (Denbaly and Vroomen, 1993), and reasonable fertilization measures were 
formulated: reduce or delay the application of $\mathrm{K}$ fertilizer, increase $\mathrm{N}$ and $\mathrm{P}$ fertilizer after jointing stage, increase $\mathrm{N}$ fertilizer in the late stage of decomposition, avoid nutrient competition of corn and straw decomposition, promote corn growth and straw decomposition, and ensure crop yield, to achieve efficient utilization of straw resources and reduce the application of chemical fertilizer.

\section{Conclusion}

This study found that the straw decomposition and nutrient release characteristics of the whole decomposition process under different organic fertilizer replacement rates are fast in the early stage $(0-20 \mathrm{~d})$ and slow in the late stage $(0-100 \mathrm{~d})$. At the end of decomposition $(100 \mathrm{~d})$, the decomposition rate and nutrient release rate were $8 \% \mathrm{OF}>16 \% \mathrm{OF}>24 \% \mathrm{OF}>\mathrm{CF}>\mathrm{CK}$, and the nutrient release characteristics of fertilization treatment were $\mathrm{K}>\mathrm{P}>\mathrm{N}>\mathrm{C}$, while $\mathrm{CK}$ was $\mathrm{K}>\mathrm{P}>\mathrm{N} \approx \mathrm{C}$. Through the establishment and analysis of decomposition and nutrient release models $\left(\mathrm{y}=\mathrm{a} \cdot \mathrm{x}^{\mathrm{b}}\right)$, dynamic monitoring and prediction of decomposition and nutrient release during corn growth period can be carried out, and the characteristics of decomposition and nutrient release in this experiment can be verified. Through the establishment of different organic fertilizer replacement rate and nutrient release model and correlation analysis, the recommended organic fertilizer replacement rate was determined to be $12 \%$, and according to the characteristics of nutrient release in this study, the strategy of comprehensive management of reasonable straw returning and fertilization in corn planting was proposed: On the basis of recommending the organic fertilizer replacement rate $(k=12 \%)$, the return of straw is carried out, Organic fertilizer and straw are applied as base fertilizer, and the amount of chemical fertilizer applied in the base fertilizer is reduced. This study is limited to the nutrient release of straw, and the nutrient absorption characteristics of corn needs further research, combined with the release characteristics of straw nutrients, which is conducive to the development of more scientific straw returning and fertilization management measures.

Acknowledgements. This research was supported by the National Key Research and Development Program of China (2017YFD0201808, 2018YFD0200406) and the National Natural Science Foundation of China (31660598, 31360501).

\section{REFERENCES}

[1] Abdou, G., Ewusi-Mensah, N., Nouri, M., Tetteh, F. M., Safo, E. Y., Abaidoo, R. C. (2016): Nutrient release patterns of compost and its implication on crop yield under Sahelian conditions of Niger. - Nutrient Cycling in Agroecosystems 105(2): 117-128.

[2] Ahlam, E. B. (2004): Assessment of rate of decomposition and nutrient release from leaf residue of some tree species. - MSc. Thesis Desertification and Desert Cultivation Studies Institute, University of Khartoum, Khartoum.

[3] Azam, F., Lodhi, A., Ashraf, M. (1991): Availability of soil and fertilizer nitrogen to wetland rice following wheat straw amendment. - Biology and Fertility of Soils 11(2): 97-100.

[4] Bao, S. D. (2000): Analysis of Soil Agrochemistry. - China Agriculture Press, Beijing, pp. 30-107. 
[5] Becker, R., Bubner, B., Remus, R., Wirth, S., Ulrich, A. (2014): Impact of multi-resistant transgenic Bt maize on straw decomposition and the involved microbial communities. Applied Soil Ecology 73(1): 9-18.

[6] Bocock, K. L., Gilbert, O. J. W. (1957): The disappearance of leaf litter under different woodland conditions. - Plant and Soil 9(2): 179-185.

[7] Chapman, S. J. (1997): Barley straw decomposition and s immobilization. - Soil Biology and Biochemistry 29(2): 109-114.

[8] Chen, J., Zhao, B. Z., Zhang, J. B., Shen, L. L., Zhang, H., Qin, S. W. (2009): Research on process of fluvo-aquic soil organic carbon mineralization in initial stage of maize growth under long-term different fertilization. - Soils 41(5): 719-725.

[9] Chen, S., Liu, Z. R., Zeng, K. (2016): Effect of straw-decomposing inoculant on decomposition of rice straw. - Chinese Journal of Environmental Engineering 10(2): 839844.

[10] Dai, W. C., Gao, M., Lan, M. L., Huang, R., Wang, J. Z., Wang, Z. F., Han, X. F. (2017): Nutrient release patterns and decomposition characteristics of different crop straws in drylands and paddy fields. - Chinese Journal of Eco-Agriculture 25(2): 188-199.

[11] Dai, Z. G., Lu, J. W., Li, X. K., Lu, M. X., Yang, W. B., Gao, X. Z. (2010): Nutrient release characteristic of different crop straws manure. - Transactions of the Chinese Society of Agricultural Engineering 26(6): 272-276(5).

[12] Denbaly, M., Vroomen, H. (1993): Dynamic fertilizer nutrient demands for corn: a cointegrated and error-correcting system. - American Journal of Agricultural Economics 75(1): 203-209.

[13] Devêvre, O. C., Horwath, W. R. (2000): Decomposition of rice straw and microbial carbon use efficiency under different soil temperatures and moistures. - Soil Biology and Biochemistry 32(11): 1773-1785.

[14] Feng, W., Zhang, L. Q., Pang, Z. W., Guo, S. Z. (2011): The economic and environmental analysis of crop residues burning and reutilization in China. - Chinese Agricultural Science Bulletin 27(6): 350-354.

[15] Fischer, G., Winiwarter, W., Cao, G. Y., Ermolieva, T., Hizsnyik, E., Klimont, Z., et al. (2010): Implications of population growth and urbanization on agricultural risks in China. - Population and Environment 33(2-3): 243-258.

[16] Fu, W., Liu, K. P., Chen, H. S., Chen, X. B., Lin, H. F., Zhang, W., Wang, K. L. (2017): Effect of partial replacement of inorganic $\mathrm{N}$ with organic manure on crop yield and soil nutrient balance in arable ecosystem in karst peak-cluster depression. - Chinese Journal of Eco-Agriculture 25(6): 812-820.

[17] Gong, Z. P., Deng, N. Z., Song, Q. L., Li, Z. T. (2018): Decomposing characteristics of maize straw returning in Songnen Plain in long-time located experiment. - Transactions of the Chinese Society of Agricultural Engineering 34(8): 139-145.

[18] Gupta, S. R., Singh, J. S. (1981): The effect of plant species, weather variables and chemical composition of plant material on decomposition in a tropical grassland. - Plant and Soil 59(1): 99-117.

[19] Hao, X. Y., Gao, W., Wang, Y. J., Huang, S. W., Tang, J. W., Jin, J. Y. (2012): Effects of combined application of organic manure and chemical fertilizers on yield and quality of tomato and soil nitrate leaching loss under greenhouse condition. - Journal of AgroEnvironment Science 31(3): 538-547.

[20] Huang, T. M., Wang, Z. H., Hou, Y. Y., Gu, C. M., Li, X., Zheng, X. F. (2017): Effects of nitrogen application on decomposition and nutrient release of returned maize straw in Guanzhong Plain, Northwest China. - Chinese Journal of Applied Ecology 28(7): 22612268.

[21] Jin, S., Zhou, F. (2018): Zero growth of chemical fertilizer and pesticide use: China's objectives, progress and challenges. - Journal of Resources and Ecology 9(1): 50-58. 
[22] Jin, S. Q., Zhou, F., Shen, G. Y. (2015): Feasible routes for reducing chemical fertilizer use with dual goals of agricultural development and non-point source pollution prevention. - Environmental Protection 43(8): 50-53.

[23] Li, F. Y., Wang, J. F. (2013): Estimation of carbon emission from burning and carbon sequestration from biochar producing using crop straw in China. - Transactions of the Chinese Society of Agricultural Engineering 29(14): 1-7.

[24] Li, F. Y., Sun, X. F., Feng, W. Q., Qin, Y. S., Wang, C. Q., Tu, S. H. (2009): Nutrient release patterns and decomposing rates of wheat and rapeseed straw. - Journal of Plant Nutrition and Fertilizers 15(2): 374-380.

[25] Li, Z. Y., Tang, H. Q., Meng, Y. C., He, T. G., Wang, J., Hu, J. M., Li, T. T., Zhang, Y. (2017): Characteristics of decomposition and nutrients release of Dolichos lablab, L.'straw under different incorporation methods. - Soil and Fertilizer Sciences in China 2: $130-135$

[26] Lin, X. X., Wu, S. L., Che, Y. P. (1992): Nylon bag method for determination of decomposition rate of organic matter in arid and semi-dry regions. - Soils 24(6): 315318.

[27] Liu, J., Zhang, J., Qin, W. J., Yang, C. C., Xie, J., Xiang, X. J., Cao, W. D., Xu, C. X. (2016): Decomposition and nutrient release characteristics of different Vicia villosa green manure applications in red soil uplands of South China. - Acta Prataculturae Sinica 25(10): 66-76.

[28] Liu, Y. R., Xiang, L. I., Shen, Q. R., Xu, Y. C. (2013): Enzyme activity in water-stable soil aggregates as affected by long-term application of organic manure and chemical fertiliser. - Pedosphere 23(1): 111-119.

[29] Murayama, S. (2010): Decomposition kinetics of straw saccharides and synthesis of microbial saccharides under field conditions. - European Journal of Soil Science 35(2): 231-242.

[30] Nakajima, M., Cheng, W., Tang, S., Hori, Y., Yaginuma, E., Hattori, S., Tawaraya, K., $\mathrm{Xu}, \mathrm{X}$. K. (2015): Modeling aerobic decomposition of rice straw during the off-rice season in an andisol paddy soil in a cold temperate region of Japan: effects of soil temperature and moisture. - Soil Sci Plant Nutr 7: 1-9.

[31] Nakajima, M., Cheng, W., Tang, S., Hori, Y., Yaginuma, E., Hattori, S., Tawaraya, K., $\mathrm{Xu}, \mathrm{X}$. K. (2016): Modeling aerobic decomposition of rice straw during the off-rice season in an andisol paddy soil in a cold temperate region of Japan: effects of soil temperature and moisture. - Soil Science and Plant Nutrition 62(1): 90-98.

[32] Ngatia, L. W., Reddy, K. R., Nair, P. K. R., Pringle, R. M., Palmer, T. M., Turner, B. L. (2014): Seasonal patterns in decomposition and nutrient release from East African savanna grasses grown under contrasting nutrient conditions. - Agriculture Ecosystems and Environment 188(15): 12-19.

[33] Stanford, G., Smith, S. J. (1972): Nitrogen mineralization potentials of soils. - Soil Science Society of America Journal 36(3): 465-472.

[34] Summerell, B. A., Burgess, L. W. (1989): Decomposition and chemical composition of cereal straw. - Soil Biology and Biochemistry 21(4): 551-559.

[35] Sun, J. F., Peng, H. Y., Chen, J. M., Wang, X. M., Wei, M., Li, W. J., et al. (2016): An estimation of $\mathrm{CO}_{2}$ emission via agricultural crop residue open field burning in China from 1996 to 2013. - Journal of Cleaner Production 112(12): 2625-2631.

[36] Tang, S. R., Cheng, W. G., Hu, R. G., Guigue, J., Kimani, S. M., Tawaraya, K., Xu, X. K. (2016): Simulating the effects of soil temperature and moisture in the off-rice season on rice straw decomposition and subsequent $\mathrm{CH}_{4}$, production during the growth season in a paddy soil. - Biology and Fertility of Soils 52(5): 739-748.

[37] Wang, J., Zhang, L., Pang, H. C., Zhang, J. (2017): Returning granulated straw for accelerating decomposition rate and improving soil fertility. - Transactions of the Chinese Society of Agricultural Engineering 33(6): 177-183. 
[38] Wang, W., Chen, C. L., Wu, X. H., Xie, K. J., Yin, C. M., Hou, H. J., Xie, X. L. (2018): Effects of reduced chemical fertilizer combined with straw retention on greenhouse gas budget and crop production in double rice fields. - Biology and Fertility of Soils 55: 8996.

[39] Wang, X. D., Chen, X. N., Wang, C. X., Tian, X. H., Wu, F. (2009): Decomposition of corn stalk in cropland with different fertility. - Transactions of the Chinese Society of Agricultural Engineering 25(10): 252-257.

[40] Wang, Y. J., Bi, Y. Y., Gao, C. Y. (2010): The assessment and utilization of straw resources in China. - Agricultural Sciences in China 9(12): 1807-1815.

[41] Wang, Y. Z., Chen, X., Shi, Y. (2013): Phosphorus availability in cropland soils of China and related affecting factors. - Chinese Journal of Applied Ecology 24(1): 260-268.

[42] Wen, Y. C., Zhang, Y. D., Yuan, L., Li, W., Li, Y. Q., Lin, Z., Zhao, B. Q. (2018): Crop yield and soil fertility response to commercial organic fertilizer substituting chemical fertilizer. - Scientia Agricultura Sinica 51(11): 2136-2142.

[43] Wu, J., Guo, X. S., Wang, Y. Q., Xu, Z. Y., Lu, J. W. (2011): Decomposition characteristics of rapeseed and wheat straw sunder different rice cultivations and straw mulching models. - Agricultural Sciences in China 44(16): 3351-3360.

[44] Yang, H. X., Zhou, M. H., Li, J. L., Liang, B., Sui, F. G. (2015): Decay and nutrient release in Vulpia myuros grasses, a species suitable for soil conservation in temperate zone orchards. - Acta Prataculturae Sinica 24(4): 208-213.

[45] Yin, H., Zhao, W., Li, T., Cheng, X., Liu, Q. (2017): Balancing straw returning and chemical fertilizers in China: role of straw nutrient resources. - Renewable and Sustainable Energy Reviews 81: 2695-2702.

[46] Zhang, L., Liu, Y., Hao, L. (2016): Contributions of open crop straw burning emissions to PM2.5 concentrations in China. - Environmental Research Letters 11(1): 014014.

[47] Zhao, N., Zhao, H. B., Yu, C. W., Cao, Q. H., Li, M., Cao, W. D., Gao, Y. J. (2011): Nutrient releases of leguminous green manures in rainfed lands. - Plant Nutrition and Fertilizer Science 17(5): 1179-1187.

[48] Zheng, D. M., Jiang, Y. J., Lu, S. Q., Zhu, C. Y. (2004): Study on decomposition and humification coefficient of organic fertilizer in arid region. - Soils and Fertilizers Sciences in China (2): 15-19.

[49] Zhou, G. X., Chen, L., Zhang, C. Z., Zhang, J. B. (2015): Effects of temperature and moisture on microbial community function responsible for straw decomposition. - Soils 47(5): 911-918. 